\title{
Recent Advances on Water Pollution Research in Africa: A Critical Review
}

\author{
Mugisha Bruce1, Ma Limin ${ }^{1,2 *}$ \\ ${ }^{1}$ College of Environmental Science and Engineering, Tongji University \\ 1239 Siping Road Shanghai, 200092, P.R. China \\ ${ }^{2}$ Key Laboratory of Yangtze River Water Environment, Ministry of Education \\ Shanghai, 200092, P.R. China \\ *Corresponding author details: Ma Limin; Imma@tongji.edu.cn
}

\begin{abstract}
Africa is favored with characteristic and natural water resources, but misuse of these asserts has been driven to extraordinary contamination of the environment. Populace development and urbanization due to improvements have moreover contributed gigantically to the present water contamination in Africa. The principal causes of contamination for surface waterways are untreated effluents released into the environment by humans and machines. Several African countries have set targets for emissions released into surface waters, but it's unclear whether they're being followed. Despite the fact that groundwater sources such as wells and boreholes are important sources of drinking water for Africans, the natural water quality of these groundwater sources is, for the most part, moo within the vicinity due to close proximity to sterile areas. Distinguished sources of water contaminations in Africa incorporate agrarian activities, mining, roadside outflows, wastes from industries and workshops, dumps and e-wastes. Oil leaks are a major problem in oil-rich African countries like Nigeria and Angola. Agrarian practices had the least impact on soil in Africa, whereas e-waste reuse has the highest quantities of $\mathrm{Pb}, \mathrm{Cu}$, and $\mathrm{Zn}(>1 \%)$. In Africa, there is a need for effective natural toxin control. This paper analyzes and summarizes the recent scholarship on water pollution on the African continent. It gives the past and current overview of the research breakthrough among the African scholars and scholars from the diaspora working on water pollution.
\end{abstract}

Keywords: water quality; water pollution; Africa

\section{INTRODUCTION}

Water is essentially helpful in almost all the domains of human life on this globe. Water accounts for two-third of the total volume of the body. Therefore, researchers have taken pollutions very seriously in developing countries [1] [2]. However, even though Africa has about $9 \%$ of the world's freshwater resources and $16 \%$ of the world's population, there is still no much research about its pollution compared to the other parts of the world. Polluted water immediately impacts people's health and has a harmful effect on the cultural, economic and social facets of human life, including social, economic, and cultural [3] [4]. According to the US Environmental Protection Agency (EPA) report, approximately thirty percent of the water on the earth is contaminated. Through EPA report, pollution is defined as a fact that damages the aesthetic, physical or chemical properties of water. [5].

The World Health Organization, which is the main UN body that has health under its responsibility has recommended the Plan for Water Safety (WSP) to prevent drinking water toxicity over the past seventeen years. However, toxins in water supplies continue to cause death in various parts of the globe, in addition to causing considerable damage to human health and the environment. [6].
According to the UN WWD Report [7], safe drinking water is not accessible to more than 1.1 billion of the world's population, $90 \%$ of them reside in Asia and Africa's continents. [7]. According to the above, to safeguard water resources, it is necessary to conduct water-related research and its polluting agents. [8] [9]. Continuous pollution assessment in the form of articles and scientific reports has resulted in the production of a set of data that provides a detailed picture of water quality as well as the identification and elimination of infectious organisms in water when epidemics and acute environmental problems occur. [10].

One of the new scientific methodologies used to monitor scientific activity and manage research is citation analysis or scientometrics. [11] [12]. Scientometrics is a quantitative research tool for analyzing scientific productivity and scientific policy., and a a scientific strategy for safeguarding water resources and avoiding pollution [13]. In response to the harmful effects of water pollution and the lack of a precise image of the status of research, this study attempts to analyze scientific results on water pollution on the African continent during the preceding two years. 


\section{MATERIALS AND METHODS}

From 2001 through the last issue published in 2021, this descriptive analysis was conducted retrospectively on all articles published in peer-reviewed journals concentrating on African water pollution and water quality. The existence of critical word' water pollution or water quality in Africa' in the paper's title were the inclusion criteria.
Data was collected by logging onto each journal's dedicated website and downloading all of the articles. The titles, summaries, and keywords of the linked publications were then assessed carefully, and the papers about water were then discussed in depth. (Figure 1).

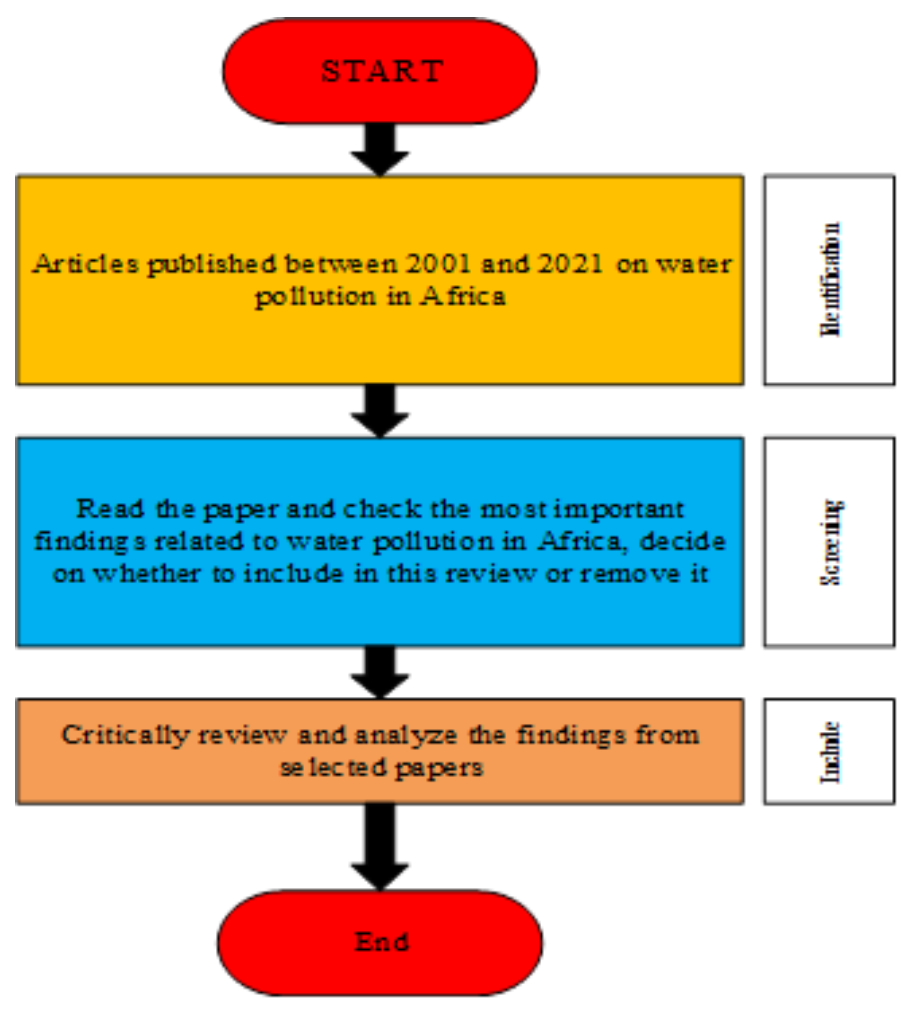

FIGURE 1: The Methodology of selecting African water pollution-related articles used in this research [14]

A researcher-made checklist was used to collect data, and there were previous experiences with it. [15][16] Recommendations for articles to formulate reports Editorial Policy and Publication Ethics Committees were chosen criteria to choose the most crucial and standard factors. [17].
The variables evaluated for analyzing the papers included the number of articles published by journals and the year they were published, the type of pollutant, the water sources surveyed, and the geographical distribution of the researchers. (Table 2)

TABLE 2: Variables studied about African water pollution-related research (2008-2017)

\begin{tabular}{ll}
\hline variables & Levels \\
\hline Sources of water & 1- Surface 2- Groundwater \\
Pollutant types and their sources & 1- Primary pollutants 2- Secondary pollutants \\
Physical variables & Classification by type \\
Microbial agents & Classification by type \\
Heavy metals & Classification by type \\
Chemical pollutants & Classification by type \\
Researchers from several countries & Name of countries \\
collaborate. & Name of continent \\
Collaborative research by continent &
\end{tabular}

The research done from the Elsevier search toll show that for the research on African water pollutions remained low for the first eight years since 2000 and have dramatically increased after as it is shown on the figure 3 below. 


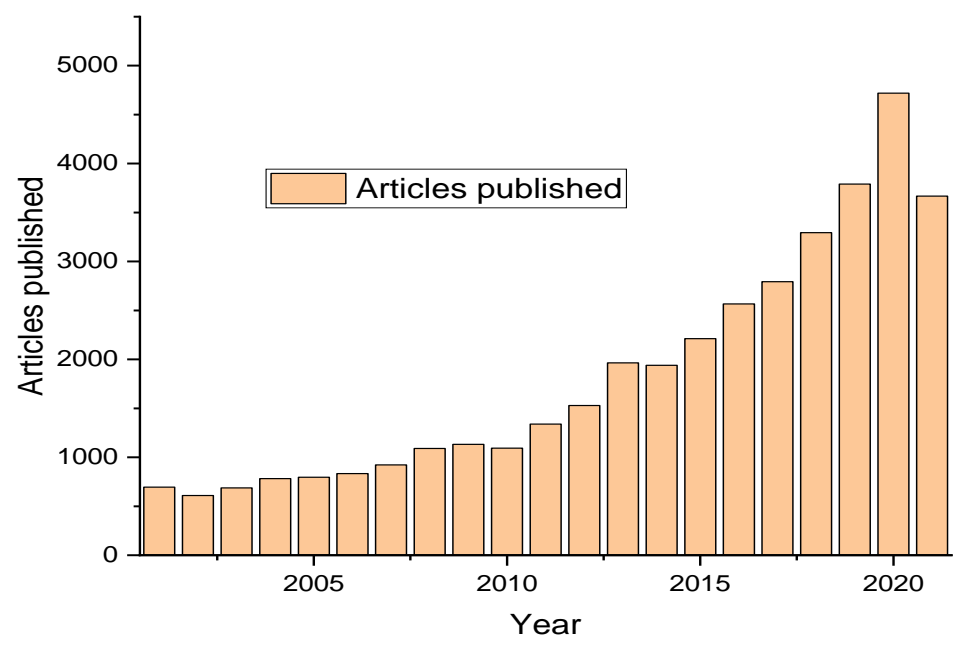

FIGURE 2: Showing the number of published articles since 2001 to 2021.

\section{THE ASSESSMENT OF WATER POLLUTION IN AFRICA}

Many scientific methods for evaluating the water pollution in Africa African and non-African researchers have put forward for these last twenty years. Some of them has demonstrated powerful applicability and others are still under discussion through academic scholars. Among the water pollution evaluations, chemical and biological methods have attracted much attention among researchers. Ernestine and Paul studied the effects of heavy metal pollution on surface and groundwater in South Africa. [18]. Wastewater treatment works effluent (WWTW), acid mine drainage effluent (AMD), and borehole water (BH.) were all used to collect water. The case study took place in the South African provinces of Mpumalanga and Limpopo. They took 15 samples and evaluated numerous characteristics to check if the effluent and water were safe to drink and use for irrigation.

The $\mathrm{pH}$ and turbidity measurements were within the South African standards' acceptable limits; however, the electric conductivity was beyond the limit. Inductively coupled plasma-mass spectroscopy was used to look for heavy metals in the samples. $\mathrm{Cu}, \mathrm{Ni}, \mathrm{Zn}$, and Ba were all found to be within the South African National Standards for drinking and irrigation set by the Department of Water and Sanitation. Fe and Mn both went beyond the limit at the same time. The metal concentrations found were not statistically significant $(\mathrm{p}>0.05)$. The data was analyzed statistically and a heavy metal pollution index (HPI) and metal index were applied (MI). All metals, $\mathrm{Cu}, \mathrm{Fe}, \mathrm{Ni}, \mathrm{Mn}$, $\mathrm{Zn}$, and $\mathrm{Ba}$, have statistically significant levels ( $\mathrm{p} \mathrm{0.05)}$ according to analysis of variance. According to the Heavy Metal Pollution Index, which is based on six heavy metals, more than 75 percent of the area has poor water quality, while less than 35 percent is appropriate. These values, however, were all below the crucial importance of 100 at all sites. Furthermore, this research shown that metals were present in considerable concentrations in newborns, children, and adults who drank water from polluted boreholes. Health risk index values less than one, on the other hand, suggest that there are few health concerns connected with drinking contaminated water. Heavy metal concentrations were used to compute health risk assessments such as chronic daily intake (CDI) and hazard quotient (H.Q.).

For infants, children, and adults, CDI values were observed in the order $\mathrm{Ba}>\mathrm{Zn}>\mathrm{Ni}>\mathrm{Cu}$ and $\mathrm{Fe}$, with heavy metals in samples collected indicating no risk to human health. Klara and his colleagues researched the sensitivity and uncertainty analysis of a continental-scale water quality model of pathogen pollution in African rivers, which revealed that model performance is a direct indication of regional and local conditions and that lessening the confusion of a single parameter may not result in significant refinements in model performance across the continent. Furthermore, their investigation revealed that only four parameters account for 93\% of output uncertainty, meaning that model performance may be significantly improved by decreasing the uncertainty of a small number of variables. [19].

A South African researcher conducted chemical and biological assessment of sewage water pollution taking Rietvlei nature reserve wetland area as a case study [20]. By examining enzymes in the organs/tissues of two fish species, biomarkers of water pollution in warm- and coldwater systems were discovered (Oreochromis mossambicus and Labeo umbratus). , Barnhoorn and his colleagues determined that the varying enzyme activity seen was caused by (1) no or too little pollution, (2) fish handling, and (3) fight in the nets, rather than pollution. In addition, the majority of the enzymes are non-specific for the contaminants present. According to their findings, when organisms are sampled from a polluted water source, the selected enzymes cannot be used as biomarkers of water pollution. [21].

Environmental contamination of the Ebrié lagoon, Western Africa's largest coastal ecosystem, was analyzed using the Driving Force-Pressure-State-Impacts-Response (DPSIR) paradigm. Through this research, the main driving forces were identified as home and industrial activity in Abidjan, as well as agricultural activities in the larger catchment region. In Abidjan, domestic effluents contribute for two-thirds of the Biological Oxygen Demand (BOD) loads and 95\% of the overall nitrogen $(\mathrm{N})$ and phosphorous (P) loads, with industry accounting for the rest. Aside from Abidjan's direct influence, the lagoon's nutrient levels are influenced by the input of nutrients from the rivers Comoé, Mé, and Agnéby, with nutrient land runoff being the most important impact. For the year 2000, total annual $\mathrm{N}$ loads to the lagoon were estimated to be $33 \mathrm{kt}$, with 45 percent coming from urban sources, 42 percent from land runoff, and 13 percent coming from atmospheric deposition. $P$ has been estimated to be 2.5 kt, 39 percent, 48 percent, and 13 percent. According to a scenario analysis, without pollution control measures, autonomous expansion will result in a five-fold increase in nutrient inputs to the lagoon between 1980 and 2050. As a result, nutrient concentrations in the lagoon would rise by a factor of three and a half, putting the entire system at risk of eutrophication. Non-point source pollution reduction programs would be the most successful in lowering nutrient concentrations. Reduced pollution at the source would 
improve the situation in Abidjan, but not significantly in other parts of the lagoon. Under the constraints of relative data scarcity, the technique used in this study has demonstrated to be effective and trustworthy enough to make policy-level conclusions. [22].

The Tuungane Project co-managed area of Lake Tanganyika in Tanzania has a mean nearshore mass-based sediment accumulation rate of $0.06 \mathrm{~g} * \mathrm{~cm} 2 *$ year- 1 (g cm$2 \mathrm{yr}-1)$ across six sites adjacent to deforested watersheds, which is double the mean rate $(0.03 \mathrm{~g} \mathrm{~cm}-2 \mathrm{yr}-1)$ at a comparable but undisturbed control site.. Spatial variation in rates is best explained by distance to deltaic point sources and bathymetric gradients. According to carbon flow statistics, organic matter burial is higher in surface sediments offshore from deforested watersheds, which corresponds to onshore land use changes that exacerbate erosion. Knowledge of sediment pollution patterns, together with maps of rocky benthic habitats, offers the necessary framework for efficient fisheries conservation planning in the current period of increased human interactions with the lake as well as its watershed. The findings can be used to improve integrated management practices in other sections of Africa's huge tropical artisanal fisheries. [23]. According to Issahaku Adam's research on Policies to Reduce Single-Use Plastic Marine Pollution in West Africa, 11 of the 16 countries have enacted bans, one has implemented a market-based instrument, and the remaining four have taken no action. The consequences of breaking a ban are serious (i.e., fines and prison sentences). However, there is little consultation when drafting limits, no national campaigns, and just a year between the announcement and execution of the ban. There are no provisions for reusable replacements. [24].

\section{WATER POLLUTION SOURCE}

Water pollution can be classified into two groups manmade and natural causes (figure 3 below). The former is defined as all dry weather pollutants that enter watercourses through pipes or channels, while the latter is defined as all nonpoint source pollutants. Storm drainage is considered nonpoint source pollution, even if the water enters watercourses via pipelines or channels. Industrial establishments and municipal wastewater treatment plants are the primary sources of point source pollution. Depending only on what is thrown down the drain", "" the range of contaminants is broad. Metals like mercury, lead, and cadmium, as well as organics like pesticides and poisons, and even radioactive elements, can all be found in water. Water derived from natural sources typically contains organisms that are involved in aquatic biogeochemical cycles. Bacteria, protists, parasitic worms, fungi, and viruses, on the other hand, can cause disease.

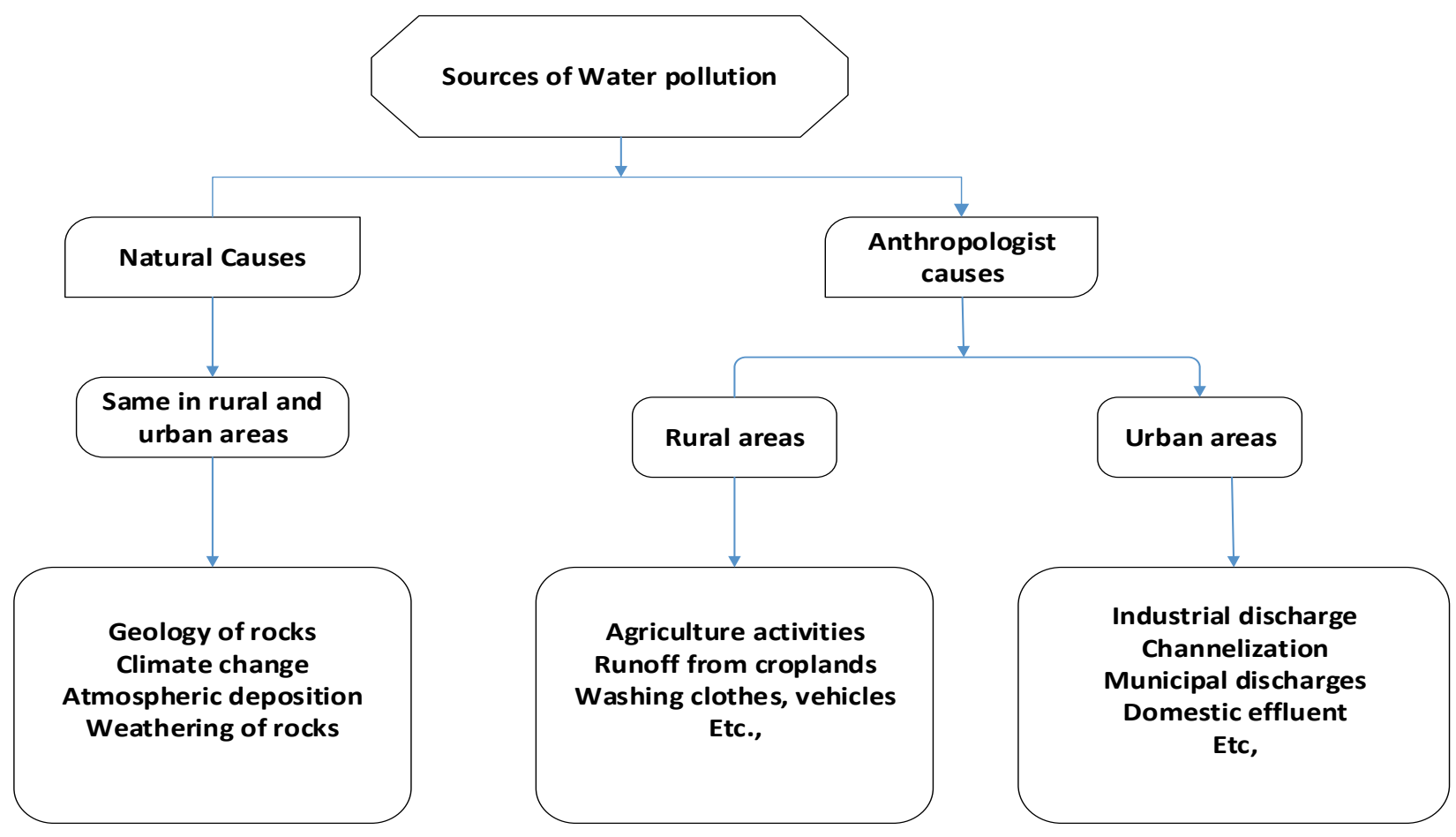

FIGURE 3: Classification and examples of water pollution sources3. Scientific remedies

Water pollution have detrimental impact on health of the human and other living organisms. For the last millennium, many species have disappeared due to the environmental pollution including water and air pollution. Eight major sources have been so far identified as the main contributor to the water pollution in Africa (see figure 4), while the effects could be different depending on the pollutants, most of the researchers has taken the water pollution as a general factor in their studies.

Nigerian scholars investigated the topic of water pollution in Dala, Kano State, Nigeria, with the goal of discovering the sources of water pollution, as well as the impacts of water pollution on public health and the environment.
That study, which was based on a primary survey of local residents as well as a secondary analysis of reports and other studies, found that inadequate waste disposal techniques are quite common, resulting in water pollution.

The study also highlighted that pollution affects the citizen's environment negatively [25]. Eddie S. Riddell and his colleagues researched on Pollution impacts on the aquatic ecosystems of the Kruger National Park in South Africa [26]. Their findings revealed that $P$ has a significant impact on macroinvertebrate ecology in the Crocodile River. It's also worth noting the P load durations in the basin as a whole. Most of the time, the remedies of water pollutions are focused on prevention instead of treatment because the former is extremely expensive. 


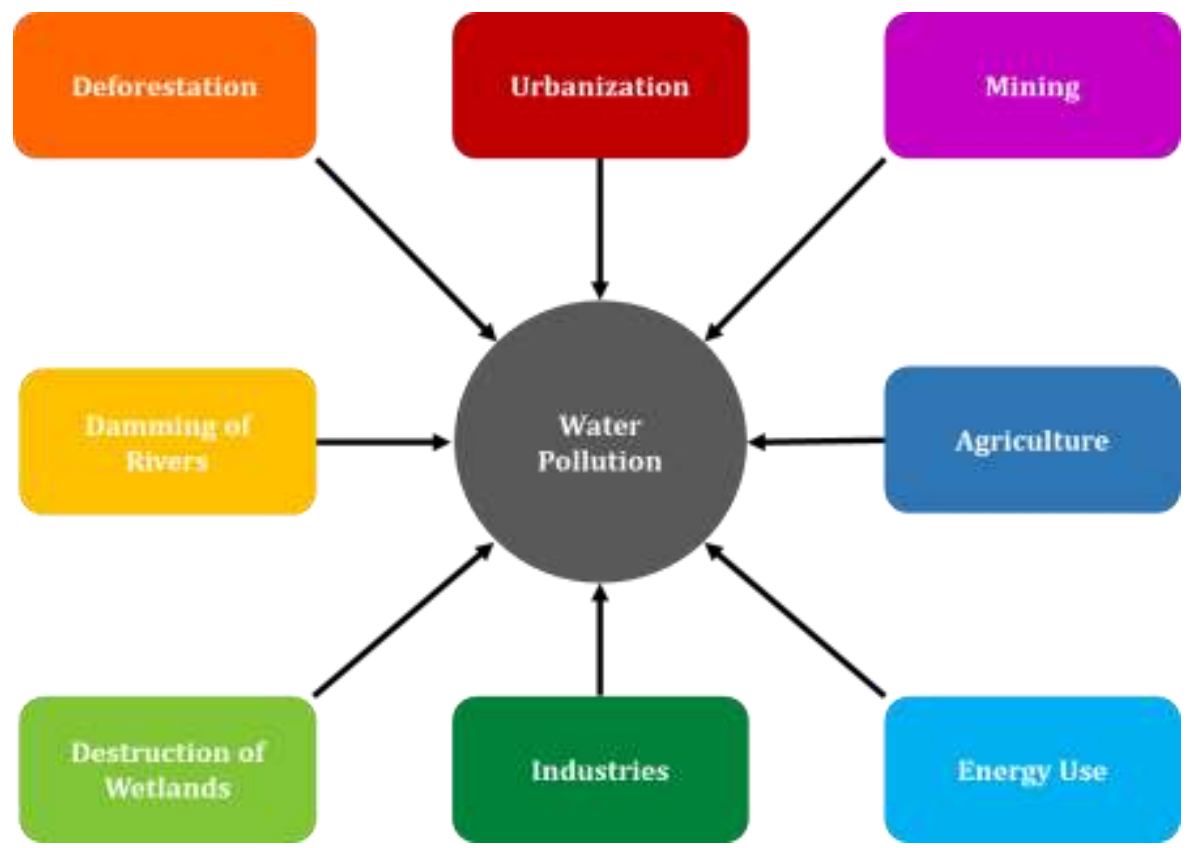

FIGURE 4: Showing the number of published articles since 2001 to 2021

\section{- Agriculture's Influence on Water Pollution in Africa}

Agriculture is among the most important contributor to the total GDP of most African countries. The agricultural gross domestic protocols show that countries like Rwanda (70\%) highly depends upon agriculture, the situation being similar to Uganda (37\%), Zambia (20\%), Kenya (33\%), Malawi (25.54), Tanzania (26,7\%) while Burundi (28. 9\%). The dependence on agriculture might lead to the conclusion that there is low water pollution. But studies have shown that uncontrolled agriculture practices might lead to heavy application of pesticides, monoculture, contamination of rivers which might affect the yield of fishery industry [50], [51]. Farming also has major impact on water contamination. Agricultural enhancer chemicals (pesticides, herbicides, insecticides, drug residues) can directly or indirectly contaminate water bodies. For example, pesticides have been found to cause fish kills, minimum fish productivity and high concentrations of undesirable chemicals in edible tissues. Controlling the use of pesticides that contain chemicals in developing countries of Africa is still a huge challenge.

However, some countries have banned some of pesticides due to their toxic effect on both plants and water. More research is needed to develop adequate cheap substitutes because the demand for more agricultural land and pesticides increases as the population increases. Africa have been importing pesticides from abroad, which also make it difficult to control the toxicity levels of pesticides [33], [52]- [54].

Agricultural practices in developing countries can limit the yield of fisheries industry in several ways. Soil erosion and the augmentation of suspended solids in waters can minimize photosynthesis and the yield of fish species that have not full adapted to turbid waters. This occurrence has been observed in Lake Baringo in Kenya and there are concerns that it might also happen in different parts of Lake Victoria due to intensive agricultural practices. However, It has been noticed that this problem is also regulated by drainage waters which can improve the productivity of the fish industry, perhaps at the expense of species diversity [34][29], [55].

In developing countries of Africa, there is constant improvement of agriculture practices, which causes the increase in number of existing industries currently available in the processing of plant and animal products, therefore, resulting in increase in the discharge of wastes, most of which are hazardous and oxidizable, most of the time containing high concentrations of suspended matter, and occasionally contaminated with toxic and inorganic chemicals. The above phenomenon causes extensive water pollution and should be prohibited by government regulations [48], [56]-[60]. In most African countries, vast national water plans supply clean water to a large proportion of the population, thereby increasing agriculture practices. The misuse of piped domestic and industrial supply chain can generate increased risk of water pollution from water-borne sewage and industrial waste. In Rwanda, for example, it was under plan to supply rural area with clean water by 2020 . However, this the water supply subsector has switched from a community management model to one public-private partnership model. It is estimated that private sectors already control about $30 \%$ of rural water supply chain private sectors already control about $30 \%$ of rural water supply chain private sectors already control about $30 \%$ of rural water supply chain and the Economic and Poverty Reduction Strategy aims for 50 percent by 2012 [32], [61].

Most African countries generate their cooking energy from the forests, which leads to deforestation in the rainforests thereby affecting the wildlife, weather patterns, ecosystems and the global warming. Moreover, deforestations increase the risk of soil erosion, forcing more fertile soil into nearby water bodies. The above effect has numerous disadvantage on plants and animals who depends on these water sources [37], [62], [63].

Most African countries large income is generated through mining activities. Even though, mining is a large contributor to many economies, it exhibits numerous drawbacks. Mining companies on the content are constantly criticized for not taking care of hazardous chemicals used after mining therefore increasing a number of dangerous dumping wastes that are difficult to treats, Researchers have shown that salts, mineral content from mining activities creates large amounts of heavy metals and has direct effect of the ' 'water's pH levels. The use of heavy metal contaminated water in irrigation of crops can reduces the growth yield but also the grown plants can contain unacceptable levels of heavy metals which might lead to discomfort after consumption [37], [41]- [44]. 


\section{- The Effect of Urbanization and Industrialization on Water Pollution Africa}

Over the last two decades, Africa has experienced significant urbanization, which has been accompanied by an increase in the concentration of the urban population in Africa's major cities. The urbanization in Africa is encouraged to minimize inter and intraregional infrastructure expenditures. Many economic activities are more unrestrained in traditional city systems. However, present development has resulted in the deconcentration of manufacturing production into smaller and larger medium-sized metropolitan regions. The larger manufacturing production is conducted in large and medium-size metropolitan areas, while production in large metropolitan areas focuses on services research and development. No standardized manufacturing has led to air and water pollution. To allow deconcentration of industry and reduce overly high urban concentration while limiting water pollution, investments in interregional transportation and telecommunications are required. It also demands fiscal deconcentration, so that interior towns may create fiscal resources and provide the services needed to compete with primate cities for industry and population. [67][68].

Due to numerous developments in African cities, there is a growing realization of the need to assess and address health hazards. However, there has been very little explicit research into how unique aspects of African urbanization and urbanisms promote risk, or how unplanned urban development in African cities increases the danger of water contamination. The demographic expansion of cities should come with a clear planned water dispersal system. However, researchers have discovered that the demographic profiles of cities, as well as the existence of informal economies and settlements, will be essential in enabling risk reduction, as will governance system reform. According to the findings, urban development actors must reconsider the consequences of their actions for water pollution risk, while risk reduction practitioners must formulate new urban development, reduce informality, reduce urban poverty, develop good infrastructure and service provision, control land management, and strengthen local governance capacity. [69]- [73].

In African cities, informal settlements are more likely to be located in dangerous regions, and people are less likely to have access to essential amenities and infrastructure that might help mitigate a variety of risks, such as piped drinking water and sewers. In addition, the settlers are unlikely to have secure tenure, which reduces their motivation to upgrade dwellings and invest in amenities. Finally, the people who live in these places are more likely to be new arrivals, have low salaries, or otherwise have limited adaptability. These qualities are both caused by and contribute to exclusion from decision-making processes, limiting settlers' capacity to effectively advocate for disease risk reduction owing to filthy environments. For new cities, it is recommended that a long plan be put out. [69][74].
The geographical development of African cities is producing a slew of ecological consequences, including changes to hydrological cycles, habitat loss, and greater demand on forests and land. New risks, such as landslides and flash flooding, are created as a result of environmental degradation. Furthermore, infant mortality is four times or more greater in poorer portions of urban populations in developing countries than in more affluent sectors. There are also significant disparities in the incidence of environmental-related infectious diseases such as tuberculosis, typhoid, and cholera, as well as exposure to air and water pollution, between richer and poorer populations. [75][71][76].

\section{IMPACTS OF WATER POLLUTION IN AFRICA}

Surface water bodies on the continent of Africa has dropped significantly. Even though, Africa water demand will exceed the currently available supplies by the end of this century. Therefore, strong measures should be put in place to tackle this challenge by carefully planning and increasing research activities while promoting maximum utilization and recycle of water. To initiate such process, the optimization of ' 'Africa's water supply unit will require careful treatment of waste water. The knowledge currently available can be used to sustain the available technology while researching more sustainable solutions (Figure 2) [27]- [33]. The water usage regulations and improvement of research activities require interdisplinary collaboration, which involves universities, government departments, and statutory bodies. The large portion of water pollution research in Africa is conducted by universities. However, the coordination of various water utilization and control of water pollution is done through the government institutions [34]. Polluted water is among the major challenge in local communities throughout Africa. It has affected the wellbeing of many communities in Africa due to the lack clean water and minimum facilities for sanitation. Researchers have shown that roughly 115 people die in Africa every hour from diseases that are closely related to poor hygiene, improper sanitation, and polluted water.

The origin of contaminated water in Africa results form a large range of sources such as dumping sites of industrial wastes such as pharmaceutical wastes, climate change, agriculture practices, mining activities, deforestations, urbanization, poor sanitation practices (Figure 3) [35][36] [37] [38]. Domestics activities in most African countries capital cities such as Lagos (Nigeria), Nairobi (Kenya), Dakar (Senegal), Kampala (Uganda) has generated large deposits of unsafe solid wastes due to overpopulations, poor sanitation. In addition, rapid migration of people in these cities has caused municipalities to provide necessary water supply chain and proper sanitation. For example, in Ghana, two decades ago, it was estimated that urban areas of Ghana could generate about $763698 \mathrm{~m} 3$ of waste water each day which could be calculated around $280 \times 106 \mathrm{~m} 3$ over oneyear period. Moreover, in rainy season non-disposed solid wastes with both biodegradable and non-biodegradable matter near highly populated area is washed away into rivers causing water pollution in underlying groundwater (Figure 5) [39]- [44]. 


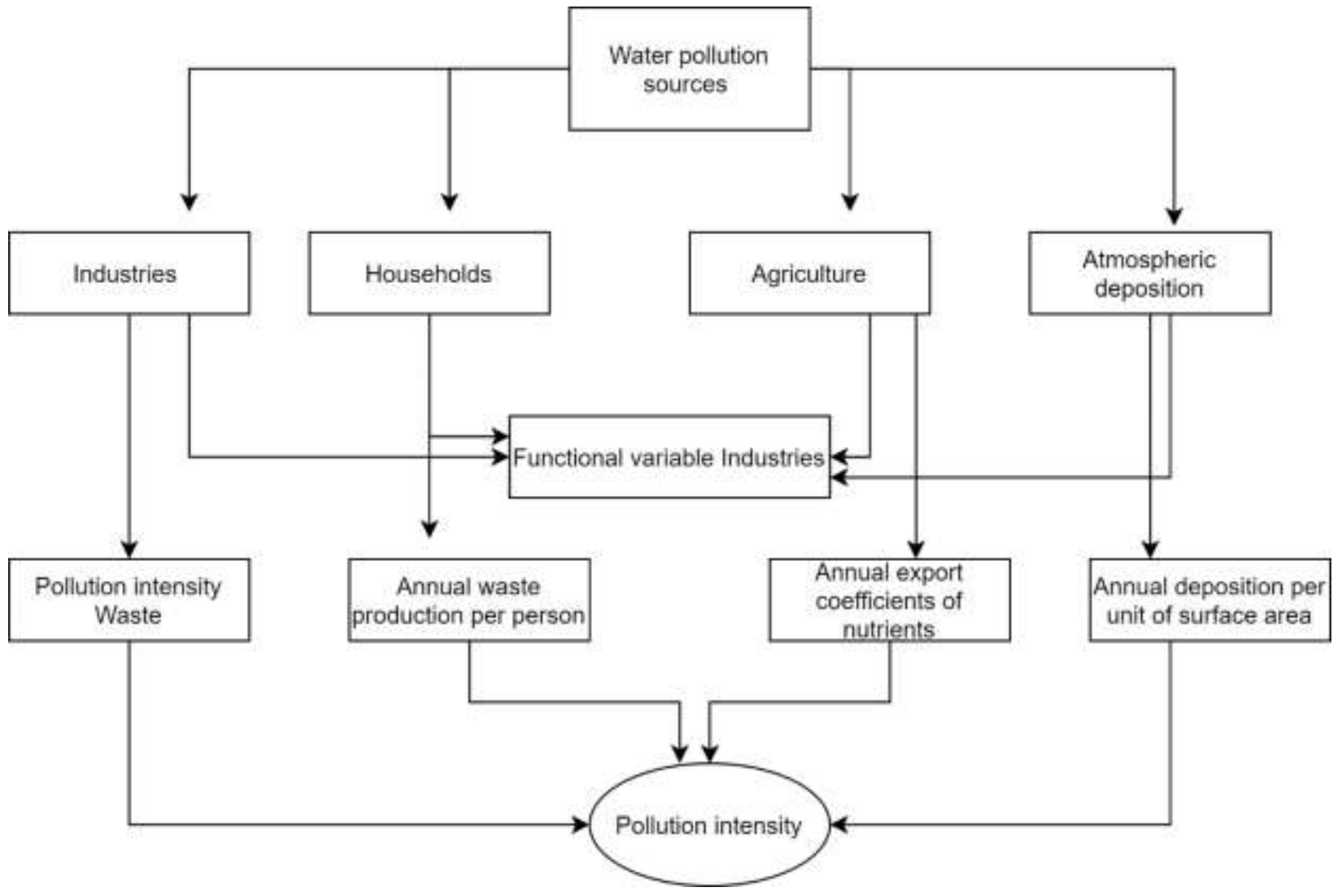

FIGURE 4: Main functional variables and pollution intensities for the principle's pollution source

E-waste in Africa has also greatly contributed to groundwater contamination due to the unplanned disposal of most e-waste on the continent by unexperienced personnel. The above have caused high contamination of ground water [45], [46][47]. Studies undertaken in mining sites have revealed that mining effluent has harmed species in the surrounding environment, particularly those found in streams and rivers. In Zambia, a study was conducted to investigate the impact of zinc and nickel on the ecology in the Chambishi and Mwambashi streams in the Chambishi District. The zinc and nickel content of samples collected at four sites along the streams at distances of $0,1250,2500,3500$, and $4000 \mathrm{~m}$ were evaluated using an atomic absorption spectrophotometer (AAS). The effect on the surrounding environment was measured. The assessment revealed high levels of zinc and nickel in water and sediment soils, particularly around discharge locations, where values of $0.18 \mathrm{mg} / \mathrm{L}$ and $0.83 \mathrm{mg} / \mathrm{L}$ of zinc and $1.36 \mathrm{mg} / \mathrm{L}$ of nickel in sediment were found. The detrimental impact was especially noticeable in the areas immediately upstream and downstream of discharge locations. [48][32], [49].

\section{IMPACT OF WATER POLLUTION ON HEALTH}

Water is the essential constituent of life support system. Nobody can survive or even have the capacity to live without water. In Africa, due to intense development most of our water bodies have become polluted due to industrial growth; urbanization and manmade wastes mainly the result of population growth. In most African slams, poor sanitation and contaminated drinking water are due to human activity and natural phenomena, which results in diseases related to poor sanitation. Sewage and other waste, industrial effluents, agricultural discharges, and industrial wastes from chemical companies; agricultural activities, fossil fuel plants, and nuclear power plants are the main contributors of water contamination. They exacerbate the problem of water contamination, rendering water unfit for human consumption, agriculture, and aquatic life. Not less than 1.3 billion people, or about half of Africa's population, lack access to basic sanitation, and more than a half billion people still consume contaminated water. As a result, thousands of children perish every day as a result of diarrhea and other water, sanitation, and hygiene-related issues, and many more are weakened by

disease. [51], [56], [64].Furthermore, research in mining areas has found that heavy metals in our water bodies pose a health risk potential. Carcinogenic minerals such as Lead, cadmium, arsenic and mercury have been quantified and found in unacceptable levels in the mining communities of Enigma, Mkpuma Akpatakpa, Ameka, Amorie, Amachara and Alibaruhu in Nigeria. The findings show that high levels of $\mathrm{Mn} 2+(63.45 \mathrm{mg} / \mathrm{L}), \quad \mathrm{Pb} 2+(11.42 \mathrm{mg} / \mathrm{L})$, $\mathrm{Ni} 2+(1.260), \quad \mathrm{Cd} 2+(15.67 \mathrm{mg} / \mathrm{L}), \quad \mathrm{Hg} 2+(2.60 \mathrm{mg} / \mathrm{L}), \quad$ As $(4.13 \mathrm{mg} / \mathrm{L}), \quad \mathrm{Se} 2+(2.68 \mathrm{mg} / \mathrm{L}), \quad \mathrm{Cr} 3+(14.60 \mathrm{mg} / \mathrm{L})$, $\mathrm{Ag}+(6.06 \mathrm{mg} / \mathrm{L}), \mathrm{Co} 2+(0.9 \mathrm{mg} / \mathrm{L})$ and $\mathrm{Zn} 2+(10.53 \mathrm{mg} / \mathrm{L})$ above the WHO recommended standard for drinking water were recorded. The health risk correlated with high accumulation of toxic heavy metals in human tissues includes risk of contracting Parkinson's disease, acrodynia, arsenicosis, selnoises and Alzheimer" 's Alzheimer's disease, hair loss, mental incapacity, and abortion women in neary by communities. Therefore, alternative water supply should be found to reduces the potential health risk that are likely to arise these vulnerable communities [54], [65], [66]. 


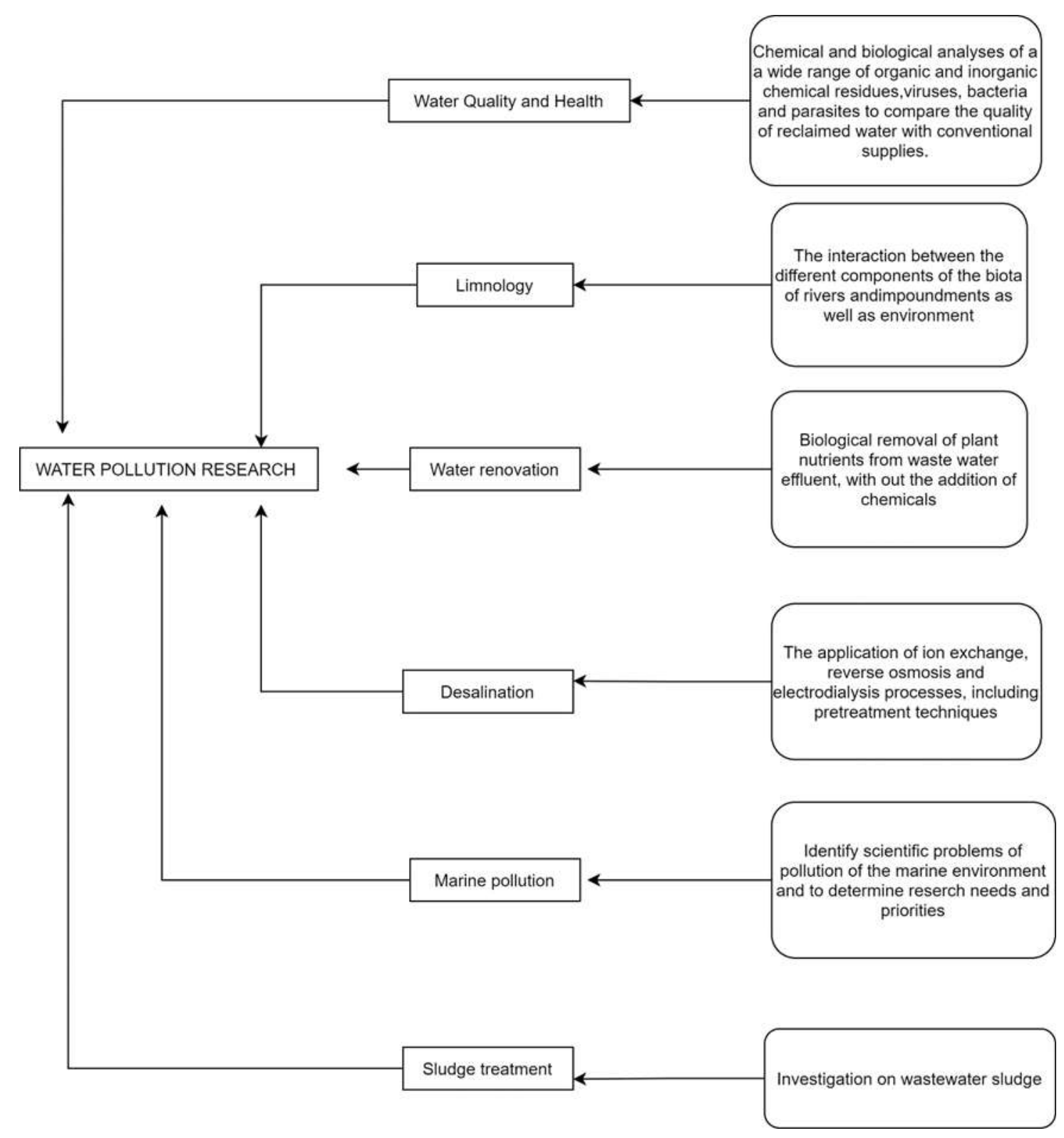

FIGURE 6: Water pollution research strategy to close the large gap of water pollution research in Africa

\section{FUTURE PROSPECTS AND RECOMMENDATIONS}

The research on water pollutions covers a wide range of points from causes to the effects and remedies for avoiding or dealing with water pollutions. The review of the recent literatures on the water pollution on the African continent shows that a lot has been done to create the awareness among researchers and policy makes on the pressing issue of this pollution. However, most of the researches are not purely scientific and has concentrated on analyzing the secondary data instead of digging deep into the science of water and its contaminants. Moreover, the research on the affordable solutions has not fully been addressed. Thus, there is need for example to study the effects of land-use change on the rivers and streams, lakes and underground waters on African continent. Samples should be collected very closely in terms of time and distances and analyzed for physical and chemical parameters (temperature, $\mathrm{pH}$, conductivity, and percentage saturation of dissolved oxygen), inorganic nutrients (NO3-, NO2-, NH4+/NH3, P043-, Si04) and dissolved major ions (Ca2+, $\mathrm{K}+, \mathrm{Mg} 2+$, $\mathrm{Na}+, \mathrm{HCO3-}$ [ [77]. The effects of land-use changes caused by urbanization on water and sediment parameters and the water living community thorough investigation but taking into account the relationship between the water living community and land-use pattern [78]. Establishing approaches to protect water pollutions and remedies in dealing with polluted water bodies should also be critically investigated. As far as urban water problems is concerned, some important areas of research are still needed to improve our understanding of the urban water cycle, and they can be summarized as follows: For the prediction of precipitation forecasts at increasingly short temporal scales, quantifying the impact of metropolitan regions on climate dynamics is critical. This will necessitate ongoing collaboration between meteorologists and hydrologists in order to better grasp the role of the UHI in various climates [79]. Infiltration rates in metropolitan areas are still poorly understood, and research has revealed that many prevailing assumptions are incorrect. To measure losses from the overall urban water cycle, researchers must first determine infiltration rates across impervious and pervious urban areas.

To combat water pollution, a set of pollution inventory methods should be implemented, which assess waste loads from pollution sources using functional variables and pollution intensities. Cities should incorporate water purifying facilities. Effect of water treatment facilities and natural water purification strategies in rivers and wetlands should be monitored constantly to ensure good water quality. Pollution from industry, domestic and agricultural activities have greatly contributed to poor water quality in African lakes. Regulations should be put into order to reduces their effect on water quality. The assessment of pollution sources will lead to the reduction of water-borne diseases and will benefit the people. 
Non-point source pollution from agricultural and forestry land uses, especially sediments, nutrients, and agrochemicals, can be addressed by community-based reforestation and afforestation, as well as catchment management activities. These methods must be continued for decades, if not tens of decades, to affect the receiving water body of this lake basin. Institutional survival is inextricably tied to effective technical interventions affecting people's and societies' collaborative efforts.

Africa must establish long-term water quality management, which necessitates the consideration of policy, technical, institutional, and financial methods. 'Africa' developing countries have limited funding with fragile or unstable institutions and limited technical capability to monitor water pollution or deal with a largely expanding water system. Africa should learn from developed nations in developing more sustainable costeffective monitoring, analytical methods and protocols, and assessment methods. Africa's traditional methods for water purification should also be considered in order to identify whether they are inefficient or useful. Public health strongly relies on the water quality available in communities. In developing countries there is a need of more centralized program to monitor water quality.

All waterways contain dissolved salts and trace elements created by natural weathering of the earth's surface, as is well known. The amount of clean water available should be examined on a regular basis. To maintain better water quality, drainage waters from irrigated lands, as well as effluent municipal sewage and industrial waste water, should be monitored. Moreover, the institutions in charge of water quality in different countries should set efficient effluent regulations and national water quality guidelines. It has been observed that most African countries has welldefined national water policy regulations due to water public health significance. Water supply is among the most essential issues, and water pollution should be prohibited at any cost. Even though long-term planning for many African countries still has different challenges and the main source of water pollution undetermined due to little information on the development of agriculture, municipal industrial, animal husbandry, aquaculture, etc.). Strategic water quality management plan and research on water pollution should be encouraged and prioritized.

\section{ACKNOWLEDGEMENTS}

This work was supported by the National Key R\&D Program of China (No. 2018YFC1803100) and the project of Tonghai Xiuqi Eco-environment Investment Co., Ltd (QT2020THXQ10). We further acknowledge all anonymous reviewers who brought the manuscript to this stage.

\section{CONFLICTS OF INTERESTS}

The author declares no conflicts of interest concerning the publication of this paper.

\section{REFERENCES}

[1] D. H. S. M. S.-H. J. P.-S. R. Aghalari Z, "Effectiveness of wastewater treatment systems in removing microbial agents: a systematic review," Glob Health, vol. 16, no. 13, 2020 .

[2] C. R. Z. S. H. C. Dai B, "A fuzzy recommendation system for daily water intake," Advances in Mechanical Engineering, vol. 8, no. 5, 2016.

[3] S. D, "Missing the millennium development goal targets for water and sanitation in urban areas," Environ Urban, vol. 29, no. 1, p. 99-118, 2016.
[4] P. P. K. T. Behailu BM, "Indigenous Practices of Water Management for Sustainable Services: Case of Borana and Konso, Ethiopia," SAGE Open, vol. 6, no. 4, 2016.

[5] S. S. Komasi M, "Surface Water Quality Assessment and Prioritize the Factors Pollute This Water Using Topsis Fuzzy Hierarchical Analysis," Jehe, vol. 4, no. 2, p. 174-184, 2017.

[6] W. H. Organization, Guidelines for drinking-water quality, vol. 1, geneva, 2008.

[7] T. U. Nations, "The United Nations world water development report 2015: water for a sustainable world".

[8] P. T. M. I. Ikonen J, "Suitability of optical, physical and chemical measurements for detection of changes in bacterial drinking water quality," Int J Environ Res Public Health, vol. 10, no. 11, p. 5349-5363, 2013.

[9] W. A. J. M. S. G. B. R. B. J. Fisher MB, "Microbiological and chemical quality of packaged sachet water and household stored drinking water in Freetown, Sierra Leone," PLoS One, vol. 10, no. 7, 2015.

[10] Z. W.Z. Z. L. Y. D. C. N. N. Yan CA, "Assessment of water quality and identification of polluted risky regions based on field observations \& GIS in the Honghe River watershed, China," PLoS One, vol. 10, no. 3, 2015.

[11] A. Z. Tirgar A, "Scientific Achievements of Medical Journals in Occupational Accidents," HDQ, vol. 3, no. 4, p. 179-184, 2018.

[12] T. A. Aghalari Z, "Topics of Disasters in Scientific Outputs of Medical Sciences: A Cross-Sectional Study," HDQ, vol. 2, no. 2, p. 47-52, 2017.

[13] T. A. A. Z. Sajjadi SA, "A content analysis of articles published in recent decade in environmental health journals with an emphasis on air pollution," J Air Poll Health, vol. 3, no. 4, p. 177-186, 2018.

[14] A. A. Z. S. M. e. a. Tirgar, "A glance at one decade of water pollution research in Iranian environmental health journals," Food Contamination, vol. 7, no. 2, 2020.

[15] S. S. A. Z. Tirgar A, "The status of international collaborations in compilation of Iranian scientific articles on environmental health engineering," Glob Health, vol. 15, no. 1, 2019.

[16] D. H. S. M. S.-H. J. P.-S. R. Aghalari Z, "Effectiveness of wastewater treatment systems in removing microbial agents: a systematic review," Glob Health, vol. 16, no. 13, 2020.

[17] W. W. site, "World Association of Medical Editors (WAME), Editorial Policy and Publication Ethics Committees. Conflict of interest in peer-reviewed medical journals".

[18] P. J. Ernestine Atangana, "Using heavy metal pollution indices to assess water quality of surface and groundwater on catchment levels in South Africa," Journal of African Earth Sciences, vol. 182, 2021. 
[19] J. KlaraReder, "A sensitivity and uncertainty analysis of a continental-scale water quality model of pathogen pollution in African rivers," Ecological Modelling, vol. 351, no. 10, pp. 129-139, 2017.

[20] A.-M. P.J.Oberholster, "Biological and chemical evaluation of sewage water pollution in the Rietvlei nature reserve wetland area, South Africa," Environmental Pollution, vol. 156, no. 1, pp. 184-192, 2008.

[21] I. Vuren, "The use of different enzymes in feral freshwater fish as a tool for the assessment of water pollution in South Africa," Ecotoxicology and Environmental Safety, vol. 59, no. 2, pp. 180-185, 2004.

[22] C. P.A.G.M.Scheren, "Integrated water pollution assessment of the Ebrié Lagoon, Ivory Coast, West Africa," Journal of Marine Systems, vol. 44, no. 1-2, pp. 1-17, 2004.

[23] M. M.McGlue, K. M.Yeager, M. J.Soreghan, MichaelBehm, I. A.Kimirei, A. S.Cohen, C. Apse, P. Limbu, R. A.Smiley, D. Doering, J. S.Lucas, AthanasioMbonde and P. B.McInytre, "Spatial variability in nearshore sediment pollution in Lake Tanganyika (East Africa) and implications for fisheries conservation," Anthropocene, vol. 33, 2021.

[24] IssahakuAdam, T. R.Walker, J. CarlosBezerra and AndreaClayton, "Policies to reduce single-use plastic marine pollution in West Africa," Marine Policy, vol. 116, no. 103928, 2020.

[25] MridulDharwal, DiptiParashar, M. Shuaibu, S. Abdullahi, S. Abubakar and B. B. Bala, "Water pollution: Effects on health and environment of Dala LGA, Nigeria," Materialstoday:proceedings, 2020.

[26] E. S.Riddell, D. Govender, J. Botha, H. Sithole, R. M.Petersen and P. Shikwambana, "Pollution impacts on the aquatic ecosystems of the Kruger National Park, South Africa," Scientific African, vol. 6, 2019.

[27] MINIFRA, "Water supply and sanitation in Rwanda:Turning Finance into Services for 2015 and beyond""," Wikimedia Inc, 2015, [Online]. Available: http://en.wikipedia.org/wiki/Water_supply_and_sa nitation_in_Rwanda.

[28] G. G. Cillie, P. Coombs, and P. E. Odendaal, "Water pollution in South Africa"'," vol. 51, no. 3, pp. 458466, 2013.

[29] J. Thomson et al., "Drawers of Water II. 30 years of change in domestic water use and environmental healt in East Africa""," Bull. World Health Organ., vol. 80, pp. 63-73, 2001, [Online].

Available:http://www.who.int/entity/bulletin/archiv es/80(1)63.pdf.

[30] M. Saddik, A. Fadili, and A. Makan, "'"Assessment of heavy metal contamination in surface sediments along the Mediterranean coast of Morocco""," Environ. Monit. Assess., vol. 191, no. 3, 2019, doi: 10.1007/s10661-019-7332-4.

[31] M. Farré, L. Kantiani, M. Petrovic, S. Pérez, and D. Barceló, "'"Achievements and future trends in the analysis of emerging organic contaminants in environmental samples by mass spectrometry and bioanalytical techniques""," J. Chromatogr. A, vol.
1259, pp. 86-99, 2012,

doi: 10.1016/j.chroma.2012.07.024

[32] P. Gwimbi, M. George, and M. Ramphalile, "Bacterial contamination of drinking water sources in rural villages of Mohale Basin, Lesotho: Exposures through neighbourhood sanitation and hygiene practices", Environ. Health Prev. Med., vol. 24, no. 1, pp. 1-7, 2019, doi: 10.1186/s12199-019-0790-z.

[33] M. Yidana, "Assessment of Heavy metal contamination levels in topsoil at selected autoworkshop in Accra,Ghana", 2015.

[34] A. O. Fayiga, M. O. Ipinmoroti, and T. Chirenje, Environmental pollution in Africa, vol. 20, no. 1 Springer Netherlands, 2018.

[35] F. O. Agunbiade and B. Moodley, "Pharmaceuticals as emerging organic contaminants in Umgeni River water system, KwaZulu-Natal, South Africa",pp. 72737291, 2014, doi: 10.1007/s10661-014-3926-Z

[36] D. J. Lapworth, N. Baran, M. E. Stuart, and R. S. Ward, "Emerging organic contaminants in groundwater: A review of sources, fate and occurrence", Environ. Pollut., vol. 163, pp. 287-303, 2012, doi: 10.1016/j.envpol.2011.12.034.

[37] T. L. Well, "What Causes Water Pollution in Africa? The Last Well".

https://thelastwell.org/2019/06/what-causeswater-pollution-in-africa/ (accessed May 29, 2021).

[38] J. E. Hickman, R. J. Scholes, and T. S. Rosenstock, "Assessing non-CO2 climate-forcing emissions and mitigation in sub-Saharan Africa", Environ. Sustain., no. Table 2, pp. 65-72, 2014, doi: 10.1016/j.cosust.2014.07.010.

[39] S. Pare and L. Y. Bonzi-Coulibaly, "Water quality issues in West and Central Africa: Present status and future challenges", IAHS-AISH Proc. Reports, vol. 361, no. July, pp. 87-95, 2013

[40] F. Kamba, F. Sangija, and S. Wei, "Impact of water pollution on human health in the Central African Republic", Adv. Soc. Sci. Res. J., vol. 3, no. 1, 2016, doi: $10.14738 /$ assrj.31.1764.

[41] P. A. G. M. Scheren, C. Kroeze, F. J. J. G. Janssen, L. Hordijk, and K. J. Ptasinski, "Integrated water pollution assessment of the Ebrié Lagoon, Ivory Coast, West Africa", J. Mar. Syst., vol. 44, no. 1-2, pp. 1-17, 2004, doi: 10.1016/j.jmarsys.2003.08.002.

[42] R. Schulz, "Using a freshwater amphipod in situ bioassay as a sensitive tool to detect pesticide effects in the field", Environ. Toxicol. Chem., vol. 22, no. 5, pp. 1172-1176, 2003, doi: 10.1897/15515028(2003)022<1172:UAFAIS >2.0.C $0 ; 2$

[43] J. Singh and D. A. Mohan, "Effect of Heavy Metal Contaminated Waste Water Irrigation on Enzymatic and Non-Enzymatic Antioxidants in Some Selected Vegetables", J. Phys. Conf. Ser., vol. 1531, no. 1, 2020, doi: 10.1088/1742-6596/1531/1/012093.

[44] J. P. R. Sorensen et al., "Emerging contaminants in urban groundwater sources in Africa", Water Res., vol. 72, pp. 51-63, 2015, doi: 10.1016/j.watres.2014.08.002. 
[45] D. O. Identifier and E. Document, "Edinburgh Research Explorer Chemical drinking water quality in Ghana: Water costs and scope for advanced treatment", 2010 , doi: 10.1016/j.scitotenv.2010.01.053.

[46] S. Moja and F. Mtunzi, "Determination of some polycyclic aromatic hydrocarbons (PAHs) associated with airborne particulate matter by high performance liquid chromatography (HPLC) method", no. April, 2014, doi: 10.5897/AJEST2013.1567.

[47] M. S. C. H. Wang et al., "Recycling from E -waste to resources", 2009.

[48] F. W. Ntengwe and K. K. Maseka, "The impact of effluents containing zinc and nickel metals on stream and river water bodies: The case of Chambishi and Mwambashi streams in Zambia", Phys. Chem. Earth vol. 31, no. 15-16, pp. 814-820, 2006, doi: 10.1016/j.pce.2006.08.027.

[49] K. Arinaitwe, D. C. G. Muir, B. T. Kiremire, P. Fellin, H. $\mathrm{Li}$, and $\mathrm{C}$. Teixeira, "Polybrominated diphenyl ethers and alternative flame retardants in air and precipitation samples from the Northern Lake Victoria Region, East Africa", Environ. Sci. Technol., vol. 48, no. 3, pp. 1458-1466, 2014, doi 10.1021/es403600a.

[50] B. Moss, "Water pollution by agriculture", Philos. Trans. R. Soc. B Biol. Sci., vol. 363, no. 1491, pp. 659666, 2008, doi: 10.1098/rstb.2007.2176.

[51] G. Thiere and R. Schulz, "Runoff-related agricultural impact in relation to macroinvertebrate communities of the Lourens River, South Africa", Water Res., vol. 38, no. 13, pp. 3092-3102, 2004, doi: 10.1016/j.watres.2004.04.045.

[52] S. Travails, "Africa' s Water Quality", R. Soc. Chem., no. March, 2010

[53] S. Mkumbo and R. Gunno, "Investigation of heavy metal pollution and health risks due to farming activities on a former dumpsite in Dar es Salaam, Tanzania", pp. 1-38, 2014.

[54] S. Gupta, S. Satpati, S. Nayek, and D. Garai, "Effect of wastewater irrigation on vegetables in relation to bioaccumulation of heavy metals and biochemical changes", Environ. Monit. Assess., vol. 165, no. 1-4, pp. 169-177, 2010, doi: 10.1007/s10661-009-0936-3.

[55] S. Sayo, J. M. Kiratu, and G. S. Nyamato, "Heavy metal concentrations in soil and vegetables irrigated with sewage effluent: A case study of Embu sewage treatment plant, Kenya", Sci. African, vol. 8, p e00337, 2020, doi: 10.1016/j.sciaf. 2020.e00337.

[56] J. Mateo-Sagasta, S. M. Zadeh, and H. Turral, "Water pollution from agriculture: A global review", food Agric. Organ. United Nations Rome, p. 35, 2017, [Online]. Available: http://www.fao.org/3/a-i7754e.pdf.

[57] F. Mapanda, E. N. Mangwayana, J. Nyamangara, and K. E. Giller, "The effect of long-term irrigation using wastewater on heavy metal contents of soils under vegetables in Harare, Zimbabwe", Agric. Ecosyst. Environ., vol. 107, no. 2-3, pp. 151-165, 2005, doi 10.1016/j.agee.2004.11.005.
[58] F. Mapanda, E. N. Mangwayana, J. Nyamangara, and K. E. Giller, "Uptake of heavy metals by vegetables irrigated using wastewater and the subsequent risks in Harare, Zimbabwe", Phys. Chem. Earth, vol. 32, no. 15-18, pp. 1399-1405, 2007, doi: 10.1016/j.pce.2007.07.046.

[59] J. O. A. Mogborukor, "'"The impact of oil exploration and exploitation on water quality and vegetal resources in a rain forest ecosystem of nigeria""," Mediterr. J. Soc. Sci., vol. 5, no. 27, pp. 1678-1685, 2014, doi: 10.5901/mjss. 2014.v5n27p1678.

[60] 0. Pourret et al., "'"Assessment of soil metal distribution and environmental impact of mining in Katanga (Democratic Republic of Congo"'")," Appl. Geochemistry, vol. 64, pp. 43-55, 2015, doi: 10.1016/j.apgeochem.2015.07.012.

[61] C. Delaire, R. Peletz, E. Kumpel, J. Kisiangani, R. Bain, and R. Khush, "How Much Will It Cost to Monitor Microbial Drinking Water Quality in Sub-Saharan Africa"?, Environ. Sci. Technol., vol. 51, no. 11, pp. 5869-5878, 2017, doi: 10.1021/acs.est.6b06442.

[62] D. A. Ridley, C. L. Heald, and B. Ford, "North African dust export and deposition: A satellite and model perspective", J. Geophys. Res. Atmos., vol. 117, no. 2, pp. 1-21, 2012, doi: 10.1029/2011JD016794.

[63] F. Ruiz et al., "The present environmental scenario of the Nador Lagoon (Morocco), Environ. Res., vol. 102, no. 2, pp. 215-229, 2006, doi: 10.1016/j.envres.2006.03.001.

[64] I. E. J. Barnhoorn and J. H. J. Van Vuren, "The use of different enzymes in feral freshwater fish as a tool for the assessment of water pollution in South Africa", Ecotoxicol. Environ. Saf., vol. 59, no. 2, pp. 180-185, 2004, doi: 10.1016/j.ecoenv.2003.09.004.

[65] P. N. Obasi and B. B. Akudinobi, "Potential health risk and levels of heavy metals in water resources of leadzinc mining communities of Abakaliki, southeast Nigeria", Appl. Water Sci., vol. 10, no. 7, pp. 1-23, 2020, doi: 10.1007/s13201-020-01233-z.

[66] B. Jiménez, "International Review for Environmental Strategies Special Feature on Groundwater Management and Policy Irrigation in Developing Countries Using Wastewater", Inst. Glob. Environ. Strateg., vol. 6, no. 2, pp. 229-250, 2006.

[67] V. Henderson, "Urbanization in developing countries"'," World Bank Res. Obs., vol. 17, no. 1, pp. 89-112, 2002, doi: 10.1093/wbro/17.1.89.

[68] Z. Ahmed, M. M. Asghar, M. N. Malik, and K. Nawaz, "Moving towards a sustainable environment: The dynamic linkage between natural resources, human capital, urbanization, economic growth, and ecological footprint in China", Resour. Policy, vol. 67, no. April, p. 101677, 2020,

doi: 10.1016/j.resourpol.2020.101677.

[69] D. Dodman, H. Leck, M. Rusca, and S. Colenbrander, "'"African Urbanisation and Urbanism: Implications for risk accumulation and reduction""," Int. J. Disaster Risk Reduct., vol. 26, pp. 7-15, 2017, doi: 10.1016/j.ijdrr.2017.06.029. 
[70] Y. T. Jung, R. J. Hum, W. Lou, and Y. L. Cheng, "Effects of neighbourhood and household sanitation conditions on diarrhea morbidity: Systematic review and meta-analysis", PLoS One, vol. 12, no. 3, pp. 1-17, 2017, doi: 10.1371/journal.pone.0173808.

[71] A. Laissaoui, J. L. Mas, S. Hurtado, N. Ziad, M. Villa, and M. Benmansour, "Radionuclide activities and metal concentrations in sediments of the Sebou Estuary, NW Morocco, following a flooding event", Environ. Monit. Assess., vol. 185, no. 6, pp. 5019-5029, 2013, doi: 10.1007/s10661-012-2922-4.

[72] M. Maanan, C. Landesman, M. Maanan, B. Zourarah, P. Fattal, and M. Sahabi, "Evaluation of the anthropogenic influx of metal and metalloid contaminants into the Moulay Bousselham lagoon, Morocco, using chemometric methods coupled to geographical information systems", Environ. Sci. Pollut. Res., vol. 20, no. 7, pp. 4729-4741, 2013, doi: 10.1007/s11356-012-1399-6.

[73] S. I. Mahomed, K. V. V. Voyi, N. H. Aneck-Hahn, and C. De Jager, "Oestrogenicity and chemical target analysis of water from small-sized industries in Pretoria, South Africa", Water SA, vol. 34, no. 3, pp. 357-363, 2008, doi: 10.4314/wsa. v34i3.180629.
[74] N. Bodin et al., "Are exploited mangrove molluscs exposed to Persistent Organic Pollutant contamination in Senegal, West Africa? Chemosphere, vol. 84, no. 3, pp. 318-327, 2011, doi: 10.1016/j.chemosphere.2011.04.012.

[75] C. Wiesner et al., "A Meta-Analysis of Global Urban Land Expansion Karen", PLoS One, vol. 7, no. 4, pp. 110, 2012, doi: 10.1371/Citation.

[76] C. G. Daughton, "Non-regulated water contaminants: Emerging research", Environ. Impact Assess. Rev., vol. 24, no. 7-8, pp. 711-732, 2004, doi: 10.1016/j.eiar.2004.06.003.

[77] R. L. M. L. G. M. d. J. M. L. d. S. Thais Carvalho Cerqueira, "Effects of urbanization on water quality in a watershed in northeastern Brazil," Environmental Monitoring and Assessment, vol. 192, no. 65, 2020.

[78] H. L. D. Z. Z. Q. Linfang Wang, "Effects of Urbanization on Water Quality and the Macrobenthos Community Structure in the Fenhe River, Shanxi Province, China," Journal of Chemistry, 2020.

[79] Arnfield, A.J., 2003. Two decades of urban climate research: a review of turbulence, exchanges of energy and water, and the urban heat island. International Journal of Climatology, 23, 1-26. doi:10.1002/(ISSN)1097-0088 